\title{
Epidermoid Cyst Located in the Fourth Ventricle: Case Report and Review
}

\section{Cisto epidermoide localizado no quarto ventrículo: relato de caso e revisão da literatura}

\author{
Arquimedes Cavalcante Cardoso ${ }^{1}$ Luiz Eurípedes Almondes Santana Lemos ${ }^{2}$ \\ Marcos Alcino Soares Siqueira Marques Júnior ${ }^{3}$ \\ ${ }^{1}$ Department of Neurosurgery, Hospital Getúlio Vargas, Teresina, PI, \\ Brazil \\ 2 Universidade Estadual do Piauí, Teresina, PI, Brazil \\ Address for correspondence Marcos Alcino Soares Siqueira Marques \\ Júnior, Rua desembargador Manoel Castelo Branco 1540, Ap 1600, \\ Jóquei, Teresina, PI, Brazil (e-mail: marcosalcinojr@gmail.com).
}

${ }^{3}$ Centro Universitário Uninovafapi, Teresina, PI, Brazil

Arq Bras Neurocir 2016;35:174-178.
Abstract
Keywords
- fourth ventricle
- epidermoid cyst
- ataxia

Epidermoid cyst is a congenital benign lesion, rarely seen in the topography of the fourth ventricle. The authors report a case of a 48-year-old patient with headache and cerebellar ataxia due to an epidermoid cyst in the fourth ventricle. We performed a surgical resection with histopathological confirmation of the lesion.

O cisto epidermoide é uma lesão congênita e benigna, sendo raro em topografia do quarto ventrículo. Os autores relatam um caso de uma paciente de 48 anos, com quadro clínico de cefaleia e ataxia cerebelar decorrentes de um cisto epidermoide localizado no quarto ventrículo. Foi realizada uma ressecção cirúrgica com confirmação anatomopatológica da lesão.

\section{Introduction}

Epidermoid cysts are benign, congenital, and rare lesions corresponding to approximately to $0.2 \%$ to $1.8 \%$ of all intracranial tumors. ${ }^{1}$ Because of its pearly appearance, in 1829 , Cruveilhier described these tumors as Tumeure Perlée. Virchow and Bailey coined the term "Pearl Tumor"; and, in 1836, Müller introduced the "Cholesteatoma" denomination. ${ }^{2}$ Approximately $5 \%$ of epidermoid cysts affects the fourth ventricle, which is one of the less common locations. ${ }^{3}$ According to Sengupta and Singh, in 2015, only 100 cases of epidermoid cyst in the fourth ventricle had been reported. ${ }^{4}$ The aim of this study is to describe the clinical characteristics of an epidermoid cyst located in the fourth ventricle and the chosen therapy, as well as provide a brief review of literature.

\section{Case Report}

This study reports on a 48-year-old woman, referring frontal occipital and pulsating headache about six months before admission. She was non-reactive to the use of analgesics, associated with nausea, dizziness, and vomiting. After two months, she developed gait disturbance, when she was diagnosed with "brain tumor," and underwent operation for placement of ventriculoperitoneal (VP) shunt. The patient was referred for this service for elective surgery for resection received

October 20, 2015

accepted

February 6, 2016

published online

April 14, 2016
DOI http://dx.doi.org/ $10.1055 / \mathrm{s}-0036-1582446$ ISSN 0103-5355.
Copyright $\odot 2016$ by Thieme Publicações License terms Ltda, Rio de Janeiro, Brazil
(ब) $\Theta \circledast$ 


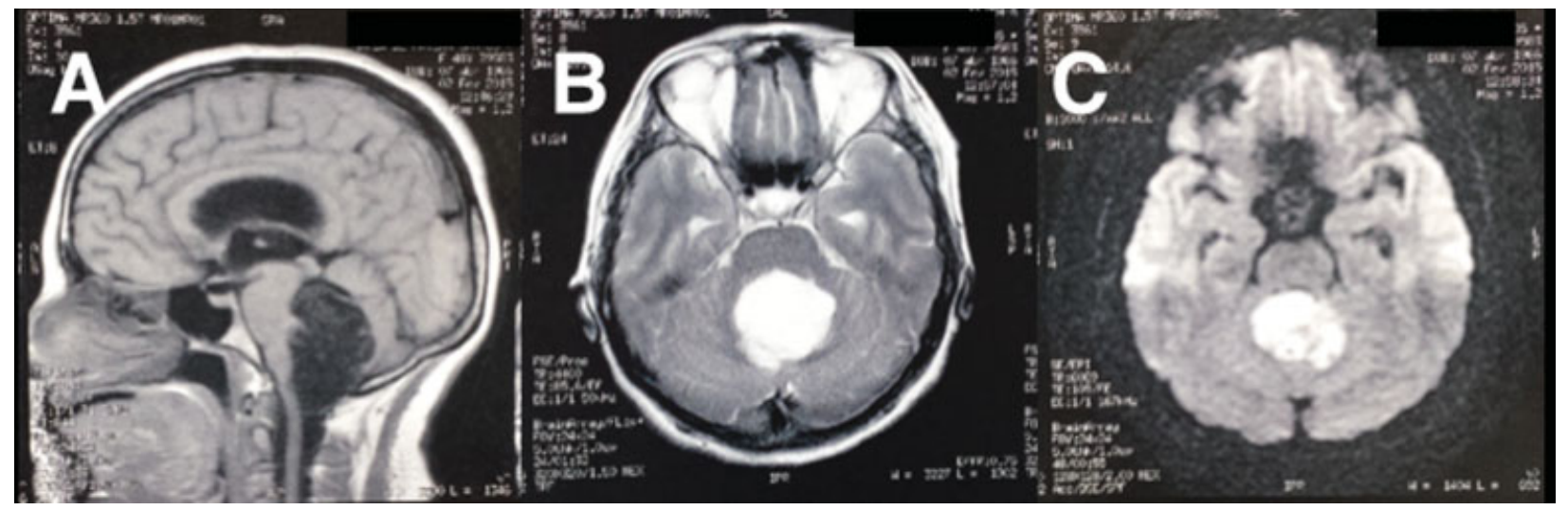

Fig. 1 Preoperative MRI scan showing a cystic lesion in the fourth ventricle. 1A: MRI T1 weighted sequence, sagittal view, with lesion isointense to cerebrospinal fluid. 1B: MRI T2 weighted sequence, axial view, with hyper intense lesion. 1C: MRI DWI, axial view, with hyper intense lesion.

of the tumor. The initial examination showed bilateral nystagmus and ataxic gait.

Magnetic resonance showed a mass lesion in the fourth ventricle, with Lushka foramen invasion, and spread to the magna cistern. It showed a hypointense appearance on T1 sequence and hyper intensity on $\mathrm{T} 2$ without enhancement after contrast injection. There was heterogeneity in FLAIR sequence and hyper intensity on the diffusion image (-Fig. 1).

During surgery, the patient was positioned in the prone position. We performed median occipital craniotomy. We achieved a gross total resection of the lesion, which had a pearly appearance (-Figs. 2 and 3). The histopathological study showed capsular tissue rich in keratin and protein, and predominantly cystic content, findings consistent with epidermoid cyst (-Fig. 4).

In the immediate postoperative period, there were no complications and the patient developed clinically well during follow-up of six months.

\section{Discussion}

The epidermoid cysts are benign, congenital, and rare, corresponding to roughly $0.2 \%$ to $1.8 \%$ of all intracranial tu-

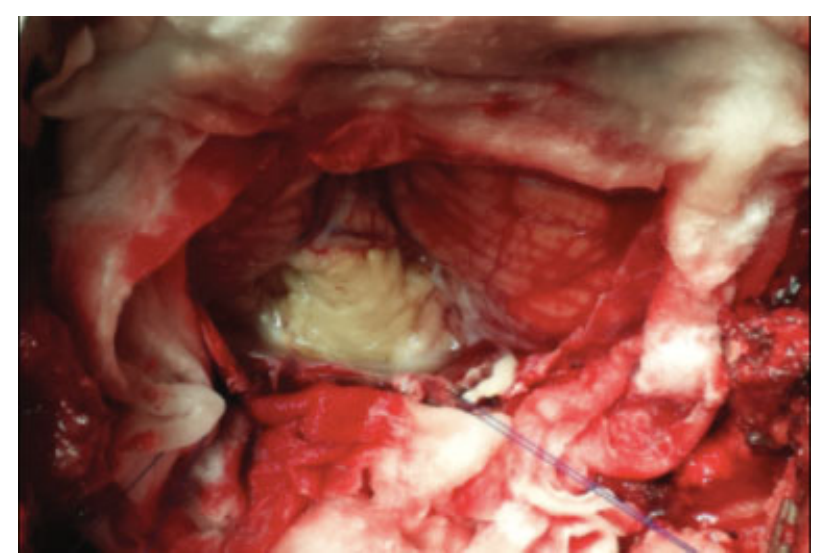

Fig. 2 Intraoperative appearance of the cyst with identifying pearly mass on topography of the fourth ventricle. mors. ${ }^{1}$ Five percent of these occur in the fourth ventricle, which is the least common location, with only $\sim 100$ cases described in the literature. ${ }^{3,4}$

Epidermoid tumors likely originate from the retention of ectodermal cells in the central nervous system because of defects of the neural tube between the third and fifth week of pregnancy. ${ }^{5}$

These tumors can occur anywhere in the intracranial cavity, but the majority is in intradural and paramedian position, especially in the pontine angle (40-50\%); or parasselar region (30\%). ${ }^{1}$ The involvement of the fourth ventricle is the least common. ${ }^{4}$

These tumors are typically asymptomatic until the fourth to fifth decade of life, presenting the average age of 40 years. Initial symptoms found in tumors affecting the fourth ventricle can include headache, dizziness, gait disturbances. ${ }^{6}$ Diplopia, dysphagia, and hoarseness may appear in later stages, when there is involvement of the cranial nerves. 3,7 In this case, we present a 48 -year-old patient whose initial symptoms were headache, nausea, vomiting, and gait ataxia, in agreement with those found in the literature.

The diagnosis of these tumors is given by the correlation between symptoms and radiographic findings. In Magnetic Resonance Imaging (MRI) on T1 sequence, they typically appear as a hypointense mass, and hyper intense on T2, and diffusion sequences. Differential diagnoses include arachnoid cysts, dermoid cysts, hydatid cyst, and neurocysticercosis. ${ }^{1,8}$

The standard treatment for epidermoid tumors is gross total surgical resection. ${ }^{1}$ In certain situations, these tumors can be adjacent to quite delicate neurovascular structures, such as the floor of the fourth ventricle. In these cases, because of the high risk of neurological morbidity, total resection must be replaced by a subtotal approach. ${ }^{3}$ In the case of tumors located in the fourth ventricle, the approach of choice is to perform a median sub occipital craniotomy. 9,10 The surgical excision is based on the intracapsular debulking and extracapsular dissection. ${ }^{11}$

However, two complications may alter the course of the disease: aseptic meningitis and malignant transformation. ${ }^{9}$ Aseptic meningitis is the main influencing factor of 


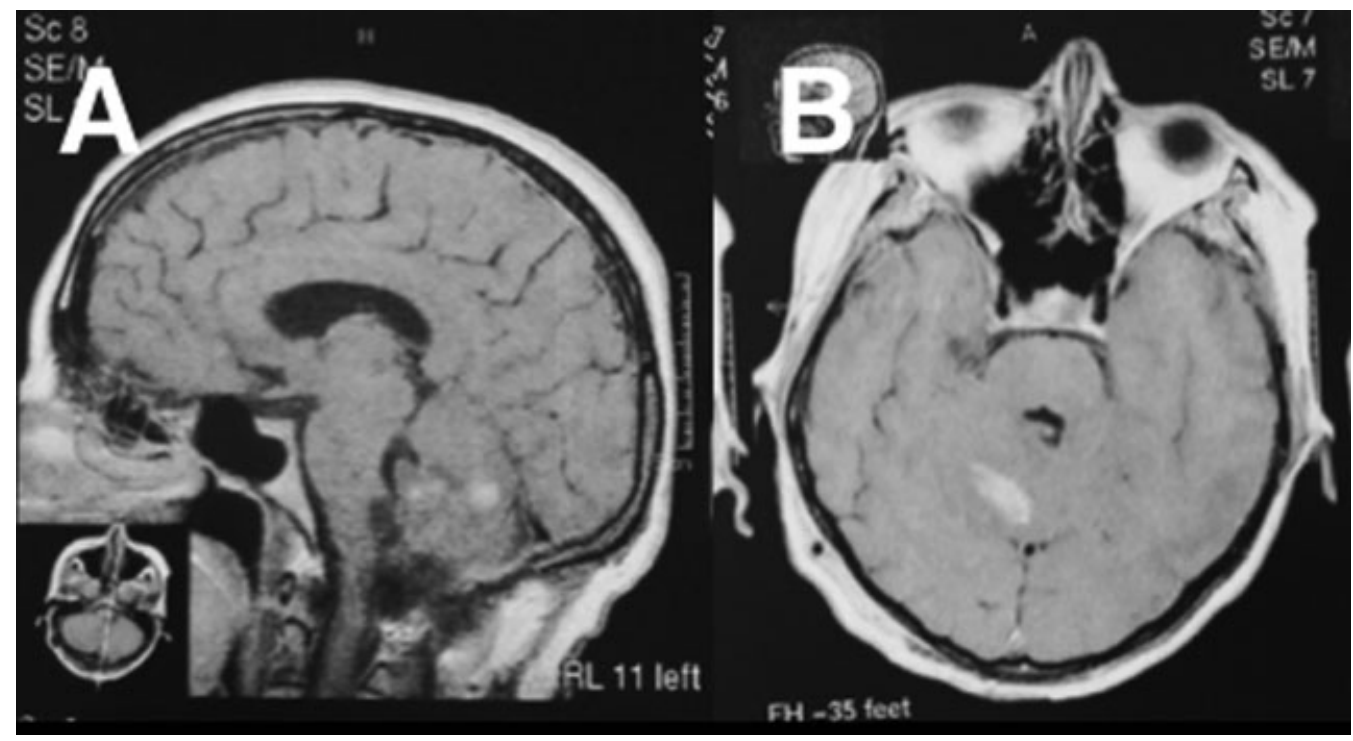

Fig. 3 Postoperative MRI scan on T1 weighted sequence showing gross total resection. (A) sagittal view. (B) axial view.

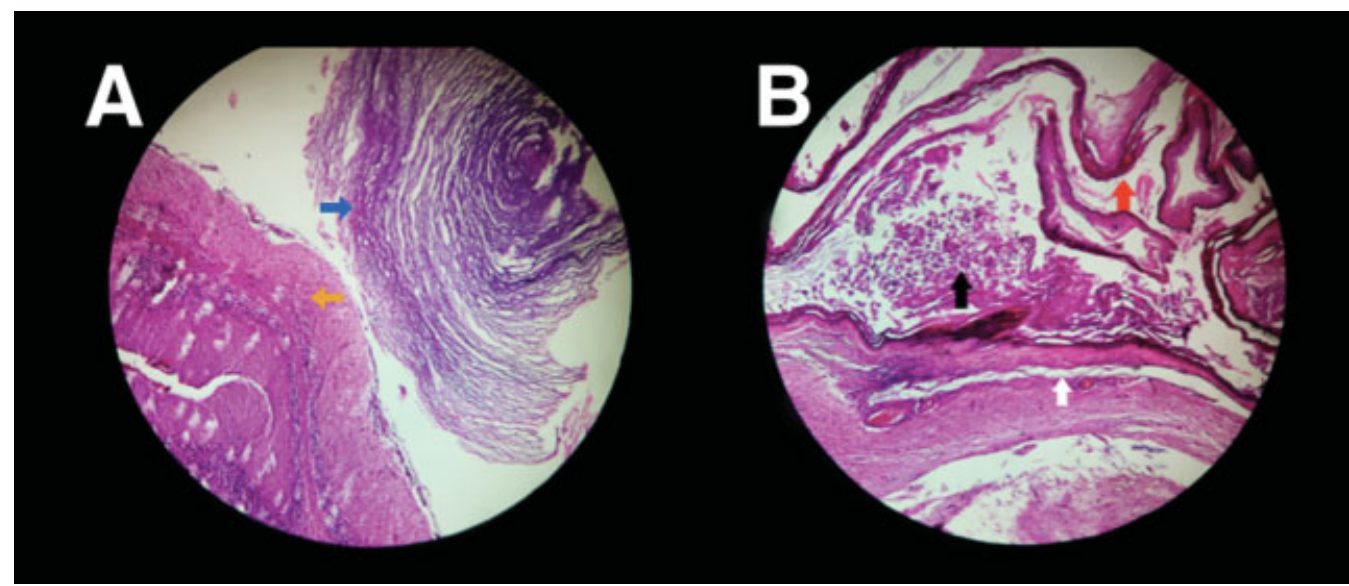

Fig. 4 Histopathological analysis of the excised tissue with 40x magnification (hematoxylin-eosin). (A) Optical microscopy image, showing healthy cerebellar tissue (yellow arrow), and richly keratinized tissue, which is the capsule of the cyst (blue arrow). (B) Cerebellar tissue (white arrow). Keratinized tissue, corresponding to the cyst capsule (red arrow). Cystic content rich in protein (black arrow).

postoperative course. ${ }^{12}$ It does not occur only when performing partial excision of the lesion, as classically described. ${ }^{9}$ For aseptic meningitis to occur, a single contact of the cystic contents of the tumor with the cerebrospinal fluid during surgery is enough. ${ }^{13}$ Treatment of aseptic meningitis is through repeated lumbar punctures and corticosteroids. ${ }^{9}$ On the other hand, malignant transformation is an extremely rare complication and, when present, is associated with the development of squamous cell carcinoma. ${ }^{14,15}$

In the case of incomplete tumor resection, although the growth rate of residual lesion is as slow as the original tumor, it is necessary to follow-up with annual magnetic resonance. ${ }^{16}$ In such cases, studies indicate recurrence of the tumor at an interval equal to the patient's age at diagnosis plus nine. ${ }^{4}$

The surgical approach must be carefully performed, and based on a combination of symptoms and radiological data, considering the slow rate of residual tumor growth. ${ }^{11}$
The literature indicates that adjuvant therapy for epidermoid cysts is scarce and, according to some authors, nonexistent. ${ }^{17}$ However, Parikh et al reported a case of success in inhibiting recurrence of a benign intracranial epidermoid cyst with the use of radiation during two years of follow-up. ${ }^{18}$

\section{Conclusion}

Epidermoid cysts of the fourth ventricle are rare and benign intracranial lesions. They tend to acquire large sizes before manifesting symptoms or cerebellar dysfunction. Early symptoms result from increased intracranial pressure, which can be minimized by placing a ventriculoperitoneal shunt. MRI is of great diagnostic value, and total surgical excision should be considered the procedure of choice. However, due to slow growth, in the case of adherence to very delicate structures of the nervous system, a subtotal approach must be considered and is associated with satisfactory results. 


\section{Conflict of Interest}

The authors declare that they have no conflict of interest.

\section{References}

1 Nagasawa D, Yew A, Safaee M, et al. Clinical characteristics and diagnostic imaging of epidermoid tumors. J Clin Neurosci 2011; 18(9):1158-1162

2 Nassar SI, Haddad FS, Abdo A. Epidermoid tumors of the fourth ventricle. Surg Neurol 1995;43(3):246-251

3 Kambe A, Anno Y, Oda N, Shiomi Y, Aoki H, Sasaki A. Reversible bilateral vestibular impairment caused by fourth ventricle epidermoid tumor. Neurol Med Chir (Tokyo) 2003;43(4):201-203

4 Sengupta SK, Singh P. Cerebellar vermian epidermal cyst. Med J Armed Forces India 2015;71(1, Suppl 1):S166-S168

5 Hossini A, Lakhdar F, Gana R, et al. Epidermoid cyst of the cisterna magna and the fourth ventricle: Report of four cases. Neurochirurgie 2012;58(6):358-363

6 Fiume D, Gazzeri G, Spallone A, Santucci N. Epidermoid cysts of the fourth ventricle. Surg Neurol 1988;29(3):178-182

7 Roka YB, Bista P, Sharma GR, Sultania PK. Cerebellopontine epidermoid presenting with trigeminal neuralgia for 10 years: a case report. Cases J 2009;2:9345

8 Doll A, Abu Eid M, Kehrli P, et al. [Aspects of FLAIR sequences, 3DCISS and diffusion-weight MR imaging of intracranial epidermoid cysts]. J Neuroradiol 2000;27(2):101-106

9 Meng L, Yuguang L, Shugan Z, Xingang L, Chengyuan W. Intraventricular epidermoids. J Clin Neurosci 2006;13(4):428-430
10 Hila H, Bouhaouala MH, Darmoul M, Jelassi H, Yedeas M. Vermian epidermoid cyst revealed by head injury. Neurochirurgie 2006; 52(1):63-66

11 Bici W, Sepehmia A, Dündar M, Sarnii M. Epidermoid tumors of the IV ventricle: Report of 3 cases. Neurocirugía 1993; 4:205-210

12 Tancredi A, Fiume D, Gazzeri G. Epidermoid cysts of the fourth ventricle: very long follow up in 9 cases and review of the literature. Acta Neurochir (Wien) 2003;145(10):905-910, discussion 910-911

13 Lopes M, Capelle L, Duffau H, et al. Surgery of intracranial epidermoid cysts. Report of 44 patients and review of the literature. Neurochirurgie 2002;48(1):5-13

14 Nakao Y, Nonaka S, Yamamoto T, et al. Malignant transformation 20 years after partial removal of intracranial epidermoid cystcase report. Neurol Med Chir (Tokyo) 2010;50(3):236-239

15 Goldman SA, Gandy SE. Squamous cell carcinoma as a late complication of intracerebroventricular epidermoid cyst. Case report. J Neurosurg 1987;66(4):618-620

16 Marin H, Vargas MI, Grebici-Guessoum M, et al. Epidermoid cyst of the fourth ventricle: four case reports. J Neuroradiol 2002; 29(3):146-152

17 Zada G, Lin N, Ojerholm E, Ramkissoon S, Laws ER. Craniopharyngioma and other cystic epithelial lesions of the sellar region: a review of clinical, imaging, and histopathological relationships. Neurosurg Focus 2010;28(4):E4

18 Parikh S, Milosevic M, Wong CS, Laperriere N. Recurrent intracranial epidermoid cyst treated with radiotherapy. J Neurooncol 1995;24(3):293-297 